\title{
Ana Muñoz-Miquel*
}

\section{Empathy, Emotions and Patient-centredness: a Case Study on Communication Strategies $^{1}$}

\begin{abstract}
One of the abilities most often associated with patient-centred communication (PCC) is empathy. But how can it be achieved? There is an extensive literature acknowledging the importance of communication skills in healthcare settings. However, few studies focus on the specific strategies that can help overcome the challenges posed by PCC, especially in dealing with, understanding and responding to emotions. This is especially evident in the field of written communication. Starting from the assumption that the way in which medical information is conveyed can significantly influence receivers' emotional response, and thus their understanding, this paper explores oral and written communication strategies that might be useful for fostering empathy. These strategies are based on the results of two funded research projects carried out by the Gentt Group (Universitat Jaume I, Spain), in which qualitative methods (interviews, focus groups and role-play with real actors) were used to improve doctor-patient communication in intralingual and interlingual contexts, in two genres: fact sheets for patients and medical consultations. The results show that avoiding ambiguous and alarming words, providing explicit explanations, using 'you' or the inclusive plural when addressing the patient, framing statements in a positive way, and explaining medical terms can all help enhance empathy, both in oral and written modes. In oral genres, non-verbal communication can also play a key role in showing genuine understanding. The importance of obtaining feedback from real patients and the potential of intralingual translation and role-play for improving the communication skills of medical professionals, translators and interpreters are also discussed.
\end{abstract}

\section{Keywords}

empathy; emotions; patient-centredness; communication strategies; fact sheets for patient; medical consultation

\section{Introduction}

Historically, the doctor-patient relationship has been approached from the perspective of a biomedical model, focusing essentially on the pathophysiology of the patient's disease and leaving the psychosocial aspect of illness and the patient's perspective unrecognised and unacknowledged (Cushing 2015, Dean/Street 2015). However, over the last few decades there has been a shift to a biopsychological model, which involves not only treating a patient's disease, but also addressing the person as a whole (Dean/Street 2015: 238). This model has clearly influenced communication: the patient takes centre stage and it is recognised that messages convey not only content but also emotions, attitudes, status, norms of interaction and expectations (du Pré/Foster 2015: 16). This patient-centred communication (PCC) involves: 1) establishing a relationship of communication on equal terms and enhancing dialogue, 2) empowering patients to take control of their

1 This article was written within the framework of the following research projects: "Improving interlingual and intercultural clinical communication: new methods for training health professionals" (FFI2015-67427-P), supported by the Spanish Ministry of Economy and Competitiveness, and "Development of online multilingual resources for the improvement of Informed Consent as an act of multimodal communication" (UJI-B2018-67), supported by Universitat Jaume I.

\footnotetext{
* Ana Muñoz-Miquel*

Departament de Traducció i Comunicació

Universitat Jaume I

E-Mail:munoza@uji.es
} 
health, 3) taking patients' needs and expectations and also their social and cultural perspectives into account, and 4) eliciting their feelings, concerns and emotions and empathising with them (Epstein/Street 2007, Arrighi et al. 2010, Brown et al. 2015, Dean/Street 2015).

One of the qualities most often associated with PCC is empathy. According to Hojat et al. (2004, in Illingworth 2015), empathy is defined as a skill that "involves an understanding of the inner experiences and perspectives of the patient as a separate individual, combined with a capability to communicate to the patient" and has been identified as the "core of caring" (Ruiz-Moral et al. 2017: 1694). In this regard, from the perspective not only of the health sciences, but also of disciplines such as social psychology, cultural anthropology, applied linguistics and translation studies, there is growing recognition of the power of empathic communication to promote healing, reduce suffering, empower patients and improve health outcomes (Brown et al. 2015, Gabbard/Smith 2015, Grupo Gentt 2016, Montalt/García-Izquierdo 2016a), and evidence with outpatients strongly indicates that when doctors respond to patients' emotions and distress, patient satisfaction increases (Kalavana 2015). This is especially evident in highly sensitive medical fields such as palliative care (Wittenberg et al. 2015) or oncology (Epstein/Street 2007), which are particularly prone to cognitive complexity and emotional intensity. But how can empathy be achieved? There is an extensive literature on the importance of communication skills in healthcare settings, but few studies focus on the specific communication strategies (terminological, textual, grammatical, pragmatic, non-verbal, etc.) that can help overcome the challenges posed by PCC, particularly when dealing with, understanding and responding to emotions. This is especially evident in the field of written communication, where these strategies are rarely addressed.

Starting from the assumption that the way in which medical information is conveyed can significantly influence receivers' emotional response and understanding, and thus their capacity to make well-informed decisions (Ragan 2015, Montalt/García-Izquierdo 2016b), this paper explores oral and written strategies that might be useful for fostering empathic communication. These strategies are based on the results of two funded research projects carried out by the Gentt Group (Universitat Jaume I, Spain), in which qualitative methods (interviews, focus groups and role-play with real actors) were used to improve doctor-patient communication in the context of two genres: fact sheets for patients (FSPs) and medical consultations. The strategies, which have been validated by the health professionals and patients who participated in the study, were used in both intralingual and interlingual communication contexts: that is, both within the same language and between different languages, where translation in the "purest" sense of the word is involved.

This paper is structured as follows: Section 2 discusses the notion of PCC, paying special attention to empathy and emotions, Section 3 describes the methods used in the two case studies that were conducted, Section 4 explains the oral and written strategies that were found most useful and Section 5 presents some concluding remarks and future challenges.

\section{Empathy and emotions in patient-centred communication}

Although PCC fosters a more equal doctor-patient relationship, there are still many asymmetries between doctors and patients as well as intrinsic and extrinsic barriers which may put communication at risk and even lead to bias, mistrust, and misunderstandings. Some of these factors, which have been pointed out by authors such as Epstein/Street (2007: 51-52), Gabbard/Smith (2015: 47), Neubauer et al. (2015: 79), Palos (2015: 157), Montalt et al. (2016) and Montalt (2017), are the following:

Cognitive and educational background: doctors and patients do not share the same medical knowledge; patients' health literacy may also be limited.

- $\quad$ Emotions, feelings and expectations: how patients feel and what they expect are determined by their attitudes, personality, prior experiences of illness, particular concerns, emotional state, the stage and nature of their disease, etc. 
- Cultural, ethnic and linguistic factors: people's beliefs and values in relation to health and disease, as well as their communicative interaction patterns (tone, eye contact, communication style, turn-taking, etc.), may differ, even if they speak the same language. The use of another language, such as English, as lingua franca also plays a significant role.

- Social and healthcare delivery factors: regulations, environment (noise, privacy), medical bureaucracy, etc.

- Demographics: age, gender, race.

PCC aims to pay special attention to these issues, since the objective is that "the clinician perspective is counterbalanced with the social, cultural, linguistic, emotional and spiritual perspectives of the individual patient" (Montalt 2017: 10). PCC thus seeks to "understand the patient as unique" (Dean/Street 2015: 238) and consider his or her specific characteristics, both medical and communicative.

According to Epstein/Street (2007) and Dean/Street (2015), there are six core functions of doctor-patient communication that are of key importance in PCC. These functions, which can be achieved by means of both verbal and non-verbal strategies, are the following:

- $\quad$ Fostering healing relationships: enhancing trust and rapport.

- Exchanging information: ensuring that patients understand and that their needs and preferences are met.

- Responding to emotions: identifying direct and indirect emotional cues and addressing them with empathy and warmth.

- Managing uncertainty: helping patients cope with uncertainty and mitigating their fears, while maintaining a balance between truth and hope.

- Making decisions: providing information, offering opportunities for involvement, encouraging participation, and accommodating patients' preferences.

- Enabling patient empowerment and self-management: providing autonomy-supportive behaviours, guidance and access to resources.

As we can see, these functions are not independent of one another and often overlap. Regarding empathy, although there is a specific function (responding to emotions) in which this ability plays a key role, it can be said to be common to all of them. Empathy - putting oneself into another person's experience - involves three dimensions, according to du Pré/Foster (2015: 16): paying attention to another person's emotions (relational), understanding those emotions (cognitive) and responding to those emotions (communicative). Therefore, empathy is also required to build healing relationships, to be able to detect when patients do not understand medical information and tailor the way in which it is delivered, or to help them make decisions and manage uncertainty.

In highly sensitive medical specialities (palliative care, oncology, infertility, etc.), the tendency is for medical professionals to remain 'neutral' and restrict themselves to providing accurate factual information (Gustin et al. 2015: 358). In medical consultations, studies suggest that when patients express emotional cues, either overtly or covertly, doctors tend to avoid such communication and focus on the medical content instead of responding with empathy (Kalavana 2015, du Pré/Foster 2015). Indeed, there is strong evidence (Illingworth 2015, Kalavana 2015, Ruiz-Moral et al. 2017) that empathy declines as medical students enter their final years of training. Recent studies carried out by the Gentt Group (Bellés-Fortuño/Molés-Cases 2019) confirm this tendency, since some of the practising doctors who were interviewed admitted that they had lost their ability to be empathic with the passage of time. The problem is that empathy has traditionally been considered intuitive and unteachable (Silverman 2015, du Pré/Foster 2015: 16), and a matter of personality, as patients themselves suggest (García-Izquierdo/Muñoz-Miquel 2015: 228). In fact, 
some studies rating students' communication skills during training, such as that conducted by Hausberg et al. (2012), suggest that the most critical issue for them is how to deal with emotion, since skills in this area are poor and difficult to develop. However, we agree with the increasing number of scholars who argue that empathic communication is a learned skill rather than an innate predisposition (Ragan 2015: 3, Ruiz-Moral 2017: 1669).

If empathy is difficult to achieve in oral interactions, the challenge is even greater in written communication. Whereas a great deal of work related to empathy in medical consultations has been done, research on written communication is scarce and seems to be in its early stages. Although there is a consensus on the importance of written genres as a way to supplement and even reinforce interactive verbal processes (Hacker 2004, Hirsh et al. 2009, García-Izquierdo/MuñozMiquel 2015), little attention has been paid to genres from the perspective of empathy. In this regard, we find some studies on patient information leaflets (Hirsh et al. 2009, Fage-Butler 2013 and 2015, Young et al. 2017) which, despite not focusing on empathy, show that patients consider that these texts "are not written with them in mind" (Fage-Butler 2015: 210) and would like more personalised genres that incorporate their experiences, knowledge and needs. It is therefore essential to explore what strategies can make oral and written communication more empathic and understandable.

In relation to medical consultations, we find an increasing number of works from health sciences aimed at medical students, which use patient-centred frameworks such as the Calgary-Cambridge Guide, ${ }^{2}$ as a basis for teaching consultation skills and offer interesting hints for fostering effective communication where empathy is acknowledged to have a key role (see, for example, Thompson et al. 2011, Tate/Tate 2014, Brown et al. 2015, Wittenberg et al. 2015). The point is that whereas in consultations, involving live conversation, it is feasible to identify what du Pré/Foster (2015: 16) call "empathic opportunities" and to provide strategies for reacting to them (i.e. eliciting concerns, allowing questions, using non-verbal language, etc.), in written genres empathy is more difficult to achieve, since there is no room for conversational adaptation, that is, for perceiving emotions and responding to them ad hoc. Although some initiatives can be found dealing with how to express empathy in the written mode in fields such as business communication, ${ }^{3}$ only a few, as far as we are aware, focus on medical and healthcare settings. One exception is the work by Lang/Esser (2012), which focuses specifically on empathy in written texts addressed to patients. These authors argue that "[m]edical writers [...] cannot merely impart facts, but they also have to demonstrate that they comprehend the patient's emotions and rationale", since "empathic writing can promote health-conscious behaviour and can foster treatment adherence" (Lang/Esser 2012: 305). They suggest that the principles of empathic texts are three: intelligibility, patient's perspective and credibility. Other works, such as those by Fage-Butler $(2013,2015)$, Fage-Butler/Jensen (2015) and Muñoz-Miquel et al. (2018), also tackle the question of empathy, but in a tangential and superficial way and do not explore particular strategies in depth. More studies are therefore needed to fill this gap.

\section{Materials and methods}

As already mentioned, the strategies proposed in Section 4 are based on the results of two independent, but complementary case studies. The following sub-sections explain the methods used in each of them.

\subsection{Case study 1: written communication}

2 The Calgary-Cambridge Guide was developed from Kurtz et al. (1998) and Silverman et al. (1998). See http:// www.gp-training.net/training/communication_skills/calgary/guide.htm. (Accessed 13 June 2019).

3 For some course offers, see http://www.writing-skills.com/wp-content/uploads/2017/11/Writing-with-empathy.pdf or https://thesearchguru.com/blog/show-empathy-writing/. (Accessed 13 June 2019). 
The object of this case study ${ }^{4}$ was to improve the written information, particularly FSPs provided for cancer patients at two public hospitals in the Valencian Community, Spain. The research was conducted with the participation of seven health professionals (doctors, nurses and psychooncologists), fourteen breast cancer patients and a team of communication experts (linguists and translators) from the Gentt Group and other universities (Aarhus University and Imperial College London). A mixed research methodology was employed, in which the data obtained were triangulated using both qualitative and quantitative methods, which included readability formulas, questionnaires, interviews and focus groups.

The research study was conducted in five phases:

1. We identified the patients' needs for written information in the form of FSPs, as well as their preferences with respect to the information they needed and how they wished to receive it. For this purpose, we interviewed health professionals and conducted focus groups with patients (for further information, see García-Izquierdo/Muñoz-Miquel 2015).

2. Then, using readability formulas and questionnaires which were created $a d$ hoc and addressed to language and communication experts, we analysed the quality and comprehensibility of thirteen FSPs provided at the participating hospitals (for further information on the methodology used in the comprehensibility analysis of the corpus see Martí 2016 and García-Izquierdo/Montalt 2017). These FSPs, on the side effects of chemotherapy, were written in Spanish by the nurses themselves, who were trying to make up for a lack of available written material to supplement the oral information patients receive. The nurses wrote them on the basis of summaries of product characteristics, a genre about medicines aimed at health professionals.

3. Taking into account the aforementioned results, we formulated an improved version of these FSPs, mainly using intralingual or expert-lay translation strategies (Zethsen 2009, 2018), ${ }^{5}$ that is, strategies used to adapt expert knowledge in the same language so that a lay reader can understand it: paraphrasing expert terms, making tenor adjustments, simplifying syntax, etc. We also made changes to optimise legibility, which involved modifying aspects of format and typography.

4. We then tested both versions of these FSPs on a sample of patients, who gave us feedback on their preferences for receiving information. For this purpose, we designed questionnaires in which patients assessed different writing strategies for enhancing understanding and empathy. They then discussed their preferences and opinions on the FSPs in focus group sessions.

5. Finally, on the basis of these results, we produced a final version of the FSPs in the light of patients' choices. This was subsequently translated by external professional translators into other languages required in the participating hospitals: Catalan, French and Romanian. It should be noted that, in line with Jensen (2015) and Zethsen (2018), the intralingual translation process that we had previously carried out to improve the original FSPs simplified this final interlingual translation task. ${ }^{6}$

\subsection{Case study 2: oral communication}

This case study ${ }^{7}$ aimed to improve the communicative and intercultural skills of healthcare professionals with patients by providing video materials to be used in educational contexts. We fo-

4 This study was conducted as part of the research project entitled "Needs analysis and proposal of written information resources for oncology patients" (FFI2012-34200), which was supported by the Spanish Ministry of Economy and Competitiveness.

5 There are several studies that focus specifically on addressing intralingual translation strategies in the medical field, from various points of view (see, for example, Ezpeleta-Piorno 2012, Muñoz-Miquel 2012, Hill-Madsen 2015, Jensen 2015, Muñoz-Miquel et al. 2018).

6 Note that the interlingual translation process could have been more complicated if other genres (such as patient-reported outcomes, where cultural adaptation is of paramount importance) had been involved (see, for example, Petkovic et al. 2015).

7 This study was conducted as part of the research projects entitled "Improving interlingual and intercultural clinical communication: new methods for training health professionals" (FFI2015-67427-P), supported by the Spanish Ministry of Economy and Competitiveness, and "Informed Consent and Medical Consultation: new methodologies for improving clinical consultation" (P1 · 1B2015-73), supported by Universitat Jaume I. 
cused on the medical consultation genre (including informed consents) in Spain and the United Kingdom.

We explored two different scenarios: 1) monolingual interactions, either in English or in Spanish, including cases in which English is used as a lingua franca by the patient and/or the doctor, and 2) bilingual interactions, including those mediated by a professional interpreter and those involving an ad hoc interpreter (usually a relative of a patient). We considered situations that are important from a linguistic, cultural and clinical point of view, such as breaking bad news, explaining different treatment options, coping with a complaining patient, addressing sexual taboos, etc.

As the main methodological and research tool we used role-plays (Skelton 2008) in which real actors participated, playing either doctors or patients. This method was combined with interviews, focus groups and questionnaires. The project involved the participation of five medical and healthcare professionals (four doctors and one psychologist), one sociologist, eight cancer patients, an acting team (composed of a stage director, a producer, five actors and two scriptwriters) and translators and communication experts from Spain (Gentt Group) and the UK (National Health Service and Refugee Council).

As explained in Montalt/Ezpeleta-Piorno (2018), the case study was conducted in three main phases:

1. First, we analysed and characterised the medical consultation genre (also including informed consents) in the Spanish and British contexts through a literature review, interviews with healthcare professionals and focus groups with patients.

2. Next, we prepared and staged the role-plays for specific clinical situations within the framework of the consultation genre in the working languages. A crucial element in this phase was collaboration and discussion among translation and communication experts, linguists, actors and medical professionals, all of whom contributed their own expertise.

3. Finally, we produced videos to be used in training contexts. The application of these videos to teaching a range of students (mainly medical professionals, but also translators and interpreters) in different training contexts will be explored in subsequent projects.

It should be noted that, within every single role-play, in which parameters such as the clinical situation, the chief complaint, the patient's symptoms, the language(s) used, the attitudes of the patient and the doctor, etc., were set, we introduced variations in the way doctors interacted with patients according to different degrees of communicative effectiveness. That is, we started from a version in which there was a lot of room for improvement. This version was subsequently modified by using different communicative strategies that followed the recommendations of the participating translators, communication experts, linguists and doctors. The aim was to reach a final version that proved more effective from a communicative point of view. A total of ten role-plays, with their respective variations, were recorded.

In order to assess the communicative strategies used and incorporate feedback from the patient, immediately after staging each medical encounter the role-player who had acted as a patient had to answer the following questions: "what did you understand?" and "how did you feel?". In this way, as in other studies carried out with medical students and simulated patients (Kalavana 2015, Ruiz-Moral et al. 2017), actors could explain their real feelings as potential patients ("I felt the doctor was interested in me as a person", "The doctor didn't seem to understand how scared I was", etc.). It is worth stressing that in this project interdisciplinary work was crucial to optimising the results.

\section{Results: written and oral strategies for dealing with empathy}

The following sub-sections provide a sample of the strategies that proved most useful according to the medical professionals' opinions and experience, the patients' needs and expectations, and the literature review. To make the analysis of results clearer, we distinguish between written and 
oral strategies, although, as with the functions of PCC (see Section 2), the strategies are interchangeable and complementary. In this regard, we agree with Montalt/García-Izquierdo (2016a: 120) that adopting a holistic view that includes both oral and written communication can contribute to a better understanding of patient-doctor communication.

\subsection{Written strategies}

When the patients compared the two versions of the FSP they commented that the improved versions overall sounded "more reassuring and comforting, and also more empathic" (García-Izquierdo/Montalt 2017: 606), as they took their prior knowledge, feelings and information needs into consideration. As mentioned in Section 3.1, patients gave us feedback on their preferences among a variety of intralingual strategies that we used to improve the FSPs (for further information on this process and the patients' preferences, see Muñoz-Miquel et. al 2018). Below we explain those strategies that patients considered more suitable. The examples given come from the FSPs and have been translated from Spanish, ${ }^{8}$ with care being taken not to change the meaning of the original statements.

\subsubsection{Adjusting tenor and personalising information}

We used personal pronouns and made the subject of actions explicit so as to sound closer to the patient, as directness was preferred. Thus, we increased the number of sentences written in the active voice, especially when an action was required of the patient. For example, 'paracetamol is recommended' was replaced by 'you can take paracetamol'; and 'it will be solved by stopping administration' by 'the healthcare staff will stop administering it'.

\subsubsection{Avoiding ambiguous words}

Ambiguous words are forms of expression that could be interpreted or defined differently by patients and doctors. One of the most illuminating examples is the use of semi-quantitative words such as "rare" when describing a potential side effect of a medication. While a doctor may interpret 'rare' as meaning, for example, a 5\% chance of occurrence, a patient suffering significant emotional distress may think that the probability is higher, especially if their experience of their illness is particularly negative. Therefore, written genres should be as explicit and clear as possible to avoid anxiety and misunderstanding. In this case, after discussing with oncologists what "rare" really meant in the context of our FSP, we replaced it with the exact figure.

\subsubsection{Checking lexical choices}

There are certain words or expressions which have no negative connotations for an average reader, but which may sound alarming, hurtful or even "offensive" (as one patient put it during the focus group sessions, García-Izquierdo/Montalt 2017: 606) for a person who is in a stressful and sensitive medical situation. Two notable examples were the lexical items 'solvent' and 'toxicity', which were considered hurtful and alarming by the participating patients. In these cases, a more neutral option was considered. 'This is due to the oil used as a solvent to dilute the drug' was replaced by 'this is due to the substances that are used to administer the drug', and 'The main toxicity is neutropenia' was replaced by 'the most common effect is a decrease in the number of white blood cells (neutropenia)'. In this second example, we can also see that an additional strategy was used: de-technicalising or de-terminologising the technical term (neutropenia), and keeping it in parentheses.

8 Some examples in Spanish from the original and modified versions can be found in Appendix 1. 


\subsubsection{De-terminologising specialised terms}

As mentioned in Section 2, one of the most important asymmetries between doctors and patients is that they do not share the same knowledge. Healthcare professionals' extensive medical knowledge represents a problem when it comes to adapting to the reader's needs. They usually find it difficult to communicate about their field in layman's terms (Zethsen 2009, Muñoz-Miquel 2012), because medical language is so ingrained in them that they often do not realise what seems like jargon to patients (Tate/Tate 2014: 107). They therefore have to "struggle to distinguish between their own knowledge and that of the receiver" (Jensen/Zethsen 2012: 45). According to patients, using specialised medical terms without providing an explanation makes them feel that their needs are not being taken into account, since no effort has been made to write in a language they can understand. Anticipating which terms and concepts will be difficult for them to understand and de-terminologising them therefore enhances not only comprehensibility but also empathy. Although de-terminologisation involves a large number of potential strategies (synonymy, explanation, comparison, replacement by a more everyday term, etc.), the one patients favoured was providing an explanation or a more 'everyday' equivalent, but keeping the technical term in parentheses. For example: 'paraesthesia' became 'pins and needles (paraesthesia)'. This strategy was also found to be useful in other studies on information for patients (for example, Fage-Butler/ Jensen 2015: 107).

\subsubsection{Framing statements in a positive way}

According to Epstein/Street (2007: 23), patients tend to respond better to statements when they are framed in terms of positive outcomes. For that reason, and in order to reduce anxiety, we gave preference to statements framed in a positive way; for example, ' $70 \%$ of patients will suffer this effect one year after treatment' was replaced by ' $30 \%$ of patients will be free from this effect one year after treatment'. However, it should be noted that according to the medical professionals that were interviewed, there has to be a balance between hope and reality, so as to avoid the information being perceived as unduly hopeful or pessimistic.

\subsubsection{Adding information}

Including information that was not present in the original version is also useful. We found that anticipating certain effects and their possible solutions made patients feel more secure and more in control of the situation, by avoiding premature anxiety and enabling them to be more involved in making informed decisions. Here are some examples:

\footnotetext{
[Original version] 'The main neurological toxicity is paraesthesia. This is an abnormal sensory symptom, especially in your hands and feet.'

[Modified version] 'Pins and needles (paraesthesias). These are abnormal sensory symptoms which take the form of a pricking, burning or tingling sensation or numbness, especially in your hands and feet. You may have difficulty doing up buttons, writing or picking up objects. Take care when handling sharp, very cold or very hot objects.'
}

Whereas in the original version, patients were only told the effect (in medical terms), in the modified version we provided a more detailed description of paraesthesias by de-terminologising the concept and adding explanations of their effect on carrying out everyday activities, so as to encourage readers to take extra care.

We also justified medical recommendations in a way that avoided mere instruction and included examples to make certain complex or abstract concepts easier to understand. For example: 'Avoid contact with people who suffer from any infectious process' was replaced by 'As your white blood cell count will be low, you should avoid contact with people who have an infectious disease (colds or flu) so as to prevent infections'. Another solution we implemented was adding 
sentences in which the patient was urged to speak to the healthcare staff if necessary (by including expressions such as 'Let staff know if [...]').

Finally, we also made some changes on a macro-textual level. Following the patients' suggestions, at the end of the FSP, we created a section for them to make a note of points they wanted to ask about on their next visit to the doctor.

\subsubsection{Including iconographic elements}

Although we focused primarily on modifying linguistic features of the text, introducing iconographic elements, i.e. pictures (particularly drawings rather than real images or photographs), into the FSP also helped to increase empathy. Although our initial intention in including pictures, in terms of the taxonomy proposed by Mayer/Gallini (1990), ${ }^{9}$ was to fulfil a decorative function (making the text more visually attractive) and, to a lesser extent, a representative function (helping the reader to visualise some event, place, person or thing), patients commented that they somehow mitigated the seriousness of the original FSP and made it more reader-friendly. We also used colours to highlight correct and incorrect behaviour (for example, foods allowed while undergoing chemotherapy were listed in a green table and those not allowed in a red table), which also enhanced understanding.

In this connection, considering the results of studies which make interesting correlations between empathy and certain images in FSPs (see, for example, Saiz-Hontangas et al. 2016 or PrietoVelasco 2017), a more thorough study of the use of images is needed, as they have the potential to play an important empathic role.

\subsection{Oral strategies}

During the preparation and staging of the role-plays, we tested a range of communication strategies, implemented in varying degrees (remember that we started from a version where there was room for improvement), for showing an empathic response in medical consultations. The following strategies were found to be particularly useful.

\subsubsection{Providing clear descriptions when explaining processes, offering responses, and giving instructions}

One of the most stressful situations for patients is not knowing what is going to happen in a medical consultation. This is particularly evident during a physical examination, especially if it is gynaecological or urological. In these cases, a strategy for reducing anxiety was to state explicitly what was going to happen and always ask permission. For example: 'Now I'm going to explore your chest to see whether $[\ldots]$ '. 'You may feel cold, but [...]'.

Descriptions were also important when responding to patients' questions regarding their state of health. These descriptions are intended to help address patients' problems and avoid judging their behaviour. For example, when a patient asks about the reason for his knee pain, it is preferable to answer 'I think you have some wear and tear, possibly a little early arthritis. So the best way to help reduce your pain is to lose weight', rather than 'You are overweight and that's why you have knee pain'. And as in the written mode (see Section 4.1.5), it is important to provide appropriate justifications for medical instructions so as to ensure adherence to treatment and therapeutic processes. Patients consider that they are more likely to do things that seem important and this is easier to achieve if they understand the reason for doing them.

9 The taxonomy that Mayer/Gallini (1990: 715) propose is the following: 1) decoration (illustrations can help the reader enjoy the text by making it more attractive, 2) representation (illustrations can help the reader visualise a particular event, person or thing, 3) narrative (illustrations can help the reader remember key information in a text; 4) organisation (illustrations can help the reader organise information into a coherent structure, and 5) interpretation (illustrations can help the reader understand the text. 


\subsubsection{Using plural pronouns and self-disclosure to establish trust and rapport}

Using plural pronouns to indicate partnership is also a useful strategy for building rapport and showing empathy; for example, when suggesting taking an action ('I hope you get better. Shall we meet in two weeks to see how you are getting on?') or when describing symptoms ('That sharp pain we sometimes feel in our belly is due to gas').

Sharing a bit about one's own experience when appropriate is also helpful as a way of showing that one really identifies with the patient's feelings and understands them, while still being professional. This can be very useful when dealing with situations that are particularly stressful or shocking (when faced with an infertility diagnosis, for example: 'I had infertility problems too and it really shook me up').

\subsubsection{Uncovering cues to emotional distress and eliciting concerns}

When patients show emotional distress, a valuable strategy is to respond to it with legitimation and validation, instead of ignoring it. 'It's natural to feel fear at this point' or 'I can see that your mother's memory loss has been very difficult to cope with' are expressions that proved to be useful ways of responding with empathy when patients overtly express their feelings. However, not all patients express their emotions, feelings, concerns and ideas directly. The health professional, therefore, needs to read behind their words and body language. A sigh, a shrug, a rueful smile, a different tone of voice, and so on, may represent empathic opportunities, as shown in Section 2, and it is necessary to respond to them with phrases that allow the patient to express his/her feelings (for example: 'I noticed you sighed earlier on when I asked you about your uncle. Is that important to you?' or 'And is there something that worries you about this pain?'). So, eliciting the concerns that the patient wishes to discuss was an effective way of reducing their anxiety and emotional block. Echoing or repeating the end of their sentence when they pause was also a good technique for encouraging further revelations (for example, 'Your mother?', 'Afraid?').

It should be noted that it is important to show genuine empathy rather than just offering perfunctory responses that sound empathic without making any effort to clarify the source of the distress. For example, if we examine the following two ways of addressing the same patient's concerns, we can see that the responses of both doctors seem "empathic", but only the second manages to detect what the patient is really worried about:

\section{Version A}

[Doctor] Is there something that particularly worries you about this headache?

[Patient] Well, I'm afraid it might get worse...

[Doctor] I understand. Don't worry. Let's have a look.

\section{Version B}

[Doctor] Is there something that particularly worries you about this headache?

[Patient] Well, I'm afraid it might get worse...

[Doctor] What do you mean by "worse"?

[Patient] Well..., something more serious.

[Doctor] What do you mean exactly?

[Patient] I'm afraid it might be a tumour.

[Doctor] Is there something that makes you think you have a tumour? 
[Patient] My uncle died of a brain tumour a few years ago.

To enhance empathy, it is also important to avoid expressions that imply that a patient's state, condition or situation is unimportant ('Don't worry!', 'It's OK! ' or 'Calm down, it's nothing, you're exaggerating'), trivialise what the patient is saying or expressing ('This is nothing; there are people who are much worse') or indicate that one does not believe them ('It can't be that painful'). Otherwise, patients may feel that their concerns are being ignored.

Finally, it is also advisable, when appropriate, to offer tangible help: 'if you need it, I can recommend a specialist to help you stop smoking'. This enhances the relationship and makes the patient feel that the interest is genuine.

\title{
4.2.4. Listening actively and leaving room for questions
}

One of the most valuable strategies for showing genuine empathy is to listen attentively to the patient. This involves a series of verbal and non-verbal strategies that signal interest in the patient, such as:

\footnotetext{
Allowing the patient to express how he/she feels, especially at the start of the consultation, instead of deliberately interrupting with closed questions, and leaving time for them to think before answering or to continue after pausing.
}

Asking open-ended questions. These do not limit the patient and give them a more active role. Explaining the rationale for these questions, when appropriate, can also stimulate unexpected responses.

Facilitating the patient's comments by echoing or paraphrasing their last words.

Leaving pauses. These help doctors to obtain more information and patients to perceive medical professionals as being more understanding.

\begin{abstract}
Maintaining eye contact, despite physical barriers (a computer screen, for example); as the CalgaryCambridge Guide advises, this means that consulting records should be postponed until the patient has completed their statement, and that listening should be separated from note reading/taking by verbal signposting.
\end{abstract}

\subsubsection{Using a forecasting style when breaking (bad) news}

Bad news, despite being stereotypically associated with a terminal diagnosis (Vandekieft 2001), can be of various kinds: a new chronic diagnosis, a worsening of a chronic illness, a need for surgery when pharmacological treatment is ineffective, etc. Although there are some protocols for delivering bad news (such as the SPIKES ${ }^{10}$ protocol in Baile et al. 2000 and Quinn 2012 or the $\mathrm{ABCDE}^{11}$ mnemonic in Vandekieft 2001), this is an area in which less standardised communication strategies can be used, as preferences among patients vary greatly (Sparks et al. 2007, García-Izquierdo/Muñoz-Miquel 2015). Doctors, therefore, need to be aware of their patients' ways of coping with information-seeking and information-avoidance and to tailor the way they deliver information accordingly (Epstein/Street 2007: 137). In our case study, it proved useful to use a forecasting style (Shaw et al. 2012, in Lane 2015), which means being as descriptive, clear and honest as possible, avoiding abstract terms, euphemisms and complex medical terminology. This involves a staged delivery (providing some warning shots, such as 'I'm afraid I have some difficult news', to prepare the patient for what is coming), but without delaying the news for too long; otherwise, patients may feel more anxiety and distress. Offering emotional support, allowing and

10 The acronym SPIKES stands for Setting up, Perception, Invitation, Knowledge, Emotions with Empathy, and Strategy or Summary.

11 The ABCDE mnemonic stands for: Advance preparation, Building a therapeutic relationship, Communicating well, Dealing with patient and family reactions, and Encouraging/validating emotions. 
respecting silence, giving space for questions, and even using touch where appropriate were also effective.

\subsubsection{Simplifying language and making explanations more understandable}

In Section 4.1, we saw that problems arising from asymmetries of knowledge are an important barrier affecting comprehension and rapport building. As both the literature review and the results of the case study show, in oral communication, this is especially evident when doctors fail to check properly that patients understand what they have been told or overlook verbal or non-verbal cues showing lack of comprehension or need for information/clarification. Therefore, some of the written strategies explained earlier can be applied to oral communication as well: explaining or paraphrasing medical concepts (de-terminologisation) or using a more popular equivalent, speaking in similar phrases to those patients use and providing examples from everyday life for comparison and to enhance understanding. It is also helpful to use visual aids (such as drawings or pictures) to explain dosages, treatment plans and so on, and to check understanding by summarising patients' explanations or asking them to restate important pieces of information.

Special care should also be taken with the words and expressions used with patients, given the devastating effect they can have on them. By way of example, a cancer patient who participated in the focus group sessions explained that the first thing the surgeon said to her when they first met was "When are they giving you the poison?" (the surgeon was referring to chemotherapy), and this question, as she put it, "did her head in" (García-Izquierdo/Muñoz-Miquel 2015: 228).

\subsubsection{Using non-verbal communication}

In oral communication, the use of non-verbal language is very helpful for achieving an empathic response. Non-verbal language includes a wide range of elements, from posture, facial expression and eye behaviour to body movements, time allowed in turn-taking and vocal cues. To enhance empathy, the following strategies proved effective: nodding to indicate understanding; smiling to show warmth; maintaining eye contact for active listening; touching or patting to show affinity, especially when breaking bad news; or leaning forward to indicate attentiveness. The use of silence was also valuable as a way of showing understanding and responding to emotions.

Through PCC and the adoption of a transactional approach to communication, "in which both parties contribute to and negotiate the meaning of messages, both verbally and non-verbally" (Ragan 2015: 4), doctors, as mentioned previously, can also take advantage of patients' non-verbal forms of expression to explore their feelings, ideas, and concerns in greater detail.

Finally, it should be borne in mind that cultural differences are especially evident in non-verbal language and that the communicative interaction patterns of doctor and patients may differ (Neubauer et al. 2015, Palos 2015), even if they speak the same language. Therefore, what is suitable in one culture can be perceived in an entirely different way in another (for some examples, see Neubauer et al. 2015). Thus, there is a need for sensitivity to cultural differences and personal preferences.

\section{Conclusions and future challenges}

This paper has presented some oral and written strategies that have proved useful for enhancing empathy. For this purpose, it has drawn on two case studies conducted by the Gentt Group, which were aimed at improving oral and written genres addressed to or involving patients, particularly the FSP and the medical consultation.

As we have seen, empathy, which involves understanding and sensitive appreciation of another person's predicament or feelings and the ability to communicate that understanding in a supportive way (Silverman 2015), plays a key role in virtually all functions of doctor-patient communication and can be enhanced by using a diverse range of verbal and non-verbal strategies. Bearing 
in mind that the same factual information can be conveyed in many different ways, the choice of these strategies can make a difference. And this choice is especially important in PCC contexts, in which it is necessary to use "adapted, contextualised solutions" (Montalt 2017: 10) to make communication more empathic and understandable.

The results of the literature review and the analysis of medical professionals' opinions and patients' preferences and needs have shown that strategies such as avoiding ambiguous or alarming words, giving clear and explicit explanations, addressing the patient by using 'you' or the inclusive plural, framing statements in a positive way, providing information about effects on everyday life, and explaining medical terms and concepts (by using de-terminologisation procedures, introducing iconographic elements, etc.) can help medical professionals to respond to emotions in a more empathic way, both in the oral and written modes, and also bridge some doctor-patient asymmetries. In oral genres, non-verbal communication (gestures, gaze, tone, etc.) can also play a key role in showing genuine understanding of a patient's feelings, although special attention should be paid to cultural differences, particularly when doctors and patients do not speak the same language or use English as a lingua franca.

In relation to oral consultations, the results have also shown that when patients do not overtly express their feelings, doctors should make the effort to pick up the patients' signals and to encourage them, verbally or non-verbally, to reveal the details of those feelings, since only in this way will they relieve patients' anxieties and make them feel reassured, listened to and empowered. This is precisely what makes empathy such a challenge in clinical practice. That is why it has traditionally been considered an innate skill. However, this paper and other studies carried out so far show that communication is a crucial part of the role of medical professionals. Providing explicit training to help them acquire these skills, which include active listening, asking open-ended questions, enquiring overtly about patients' concerns, and leaving pauses, among other strategies, is, therefore, of paramount importance. A role-play methodology in which variations in the communicative strategies used are introduced to reach a more effective doctor-patient interaction than that which served as a starting point is useful to achieve this goal.

The relevance of paying attention to written genres, and not only to oral interactions, when addressing empathy has also been pointed out. As we have seen throughout this article, the fact is that while oral communication allows for ad hoc adaptation and adjustment while the conversation is taking place, the potential pitfalls faced by a reader of written genres have to be anticipated in advance (for example, terms that may be perceived as hurtful, expressions that may sound too impersonal or detached, etc.). Although efforts are being made within Translation Studies to develop conceptual frameworks intralingual or expert-lay translation (Zethsen 2009, 2018, Jensen 2015), user-centred translation (Suojanen et al. 2015) or audience design (Mason 2000, Montalt et al. 2016) in which the receiver takes centre stage, they focus primarily on comprehensibility. Therefore, despite the fact that comprehensibility and empathy are very closely related, more efforts are needed to explore what makes written communication more empathic. And to achieve this, research with patients is essential.

This study has certain limitations. On the one hand, the sample of FSPs that were analysed, tested and improved was relatively small, as was the range of role-plays that were developed. On the other hand, the strategies identified can only be applied to the genres, languages and contexts we worked with. Hence there is a need for studies that consider other settings with larger and more varied corpora and samples of patients. As already suggested, it is also necessary to continue actively involving patients in the process of formulating, testing and improving written and oral genres addressed to or concerning them, since they are the ultimate healthcare recipients. Some proposals would be to conduct surveys using an instrument such as that proposed by Makoul/van Dulmen (2015) to assess patients' perception of communication and empathy in medical consultations; to analyse patients' narratives and forums so as to identify the empathic communication strategies they use when talking to other patients about similar concerns; and to design role-plays with the participation of real patients. 
Despite these limitations, we consider that the strategies set out here can be used to improve communicative skills, both oral and written, in healthcare settings. It is, therefore, worth continuing to develop the role of intralingual translation and role-play as methodological tools for training both medical professionals (Bittner et al. 2015) and medical translators, interpreters and writers (Muñoz-Miquel et al. 2018). For this purpose, in view of the positive results that cooperation has yielded in this study, interdisciplinary and interprofessional collaboration involving translators, linguists, communication experts, doctors, actors and others needs to be further fostered. In our view, translation studies as well as other disciplines of the humanities (communication studies, semiotics, applied linguistics, etc.) are capable of contributing to the process of improving communication in a very broad sense. In an era of increasing automation and technological change, we need to investigate new professional opportunities in which the human factor is not only necessary, but of paramount importance. And as García-Izquierdo/Montalt (2013: 7) point out, translators/interpreters (in collaboration with medics) are well placed to understand the kind of work involved in PCC and the importance of mediation between two different discourse communities (Bazerman 2012 in García-Izquierdo/Montalt 2016a), i.e. doctors and patients, by virtue of their insights into linguistic and cultural aspects of communication and their awareness of the specific needs of both groups. Thus, our task, starting from a broader, more inclusive and more interdisciplinary view of translation and interpreting as a profession (Dam/Brøgger/Zethsen 2018), is to continue exploring what translation can contribute to society. 


\section{References}

Arrighi, Emilia/Jovell, Albert J./Navarro, María Dolores 2010: El valor terapéutico en oncología. La perspectiva de pacientes, familiares y profesionales. In Psicooncología 2-3:7, 363-374.

Baile, Walter F./Buckmanb, Robert/Lenzia, Renato/Globera, Gary/Bealea, Estela A./Kudelkab, Andrzej P. 2000: SPIKES-A Six-Step Protocol for Delivering Bad News: Application to the Patient with Cancer. In The Oncologist 5:4, 302-311. doi: 10.1634/theoncologist.5-4-302.

Bazerman, Charles 2012: Issue brief: Discourse communities. In National Council of Teachers of English [online]. http://www2.ncte.org/ (accessed 13 June 2019).

Bellés-Fortuño, Begoña/Molés-Cases, Teresa 2019: El aprendizaje de la competencia comunicativa aplicada al contexto clínico: presentación de un estudio piloto. In Castellano Martínez, José María/Ruiz Mecua, Aurora (eds.), La Traducción y la Interpretación en contextos especializados: un enfoque multidisciplinar para la Transmisión del conocimiento científico. Madrid: Comares, 37-45.

Bittner, Anja/Jonietz, Ansgar/Bittner, Johannes/Beickert, Luise/Harendza, Sigrid 2015: Translating medical documents into plain language enhances communication skills in medical students - A pilot study. In Patient Education and Counseling 98, 1137-1141. doi: 10.1016/j.pec.2015.05.024

Brown, Jo/Kidd, Jane/Noble, Lorraine/Papageorgiou, Alexia (eds.) 2015: Clinical Communication in Medicine. New Jersey: John Wiley \& Sons.

Cushing, Annie 2015: History of the Doctor-Patient Relationship. In Brown, Jo/Kidd, Jane/Noble, Lorraine/Papageorgiou, Alexia (eds.), Clinical Communication in Medicine. New Jersey: John Wiley \& Sons, 6-20.

Dam, Helle V./Brøgger, Matilde N./Zethsen, Karen K. (eds.) 2018: Moving Boundaries in Translation Studies. London: Routledge.

Dean, Marleah/Street Jr., Richard L. 2015: Patient-Centered Communication. In Wittenberg, Elaine/Ferrell Betty/Goldsmith, Joy/Smith, Thomas/Ragan, Sandra/Glajchen, Myra/Handzo, George F. (eds.), Textbook of Palliative Care Communication. Oxford: Oxford University Press, 238-245.

Du Pré, Athena/Foster, Elissa 2015: Transactional Communication. In Wittenberg, Elaine/Ferrell Betty/Goldsmith, Joy/ Smith, Thomas/Ragan, Sandra/Glajchen, Myra/Handzo, George F. (eds.), Textbook of Palliative Care Communication. Oxford: Oxford University Press, 14-21.

Epstein, Ronald M./Street, Jr., Richard 2007: Patient-Centered Communication in Cancer Care. Promoting Healing and Reducing Suffering. Bethesda: National Cancer Institute.

Ezpeleta-Piorno, Pilar 2012: An example of genre shift in the medicinal product information genre system. In Linguistica Antverpiensia 11, 167-187.

Fage-Butler, Antoinette M. 2013: Improving patient information leaflets: Developing and applying an evaluative model of patient-centredness for texts. In Communication and Medicine 10:2, 105-115. doi: 10.1558/cam.v10i2.105.

Fage-Butler, Antoinette M. 2015: Package leaflets for medication in the EU: The possibility of integrating patients' perspectives in a regulated genre? In Medical Writing, 24:4, 210-214. doi:10.1179/2047480615Z.000000000325.

Fage-Butler, Antoinette M./Jensen, Matilde N., 2015: Patient- and family-centered written communication in the palliative care setting. In Wittenberg, Elaine/Ferrell Betty/Goldsmith, Joy/Smith, Thomas/Ragan, Sandra/Glajchen, Myra/Handzo, George F. (eds.), Textbook of Palliative Care Communication. Oxford: Oxford University Press, 102-110.

Gabbard, Jennifer/Smith, Thomas 2015: Communication in Palliative Medicine. In Wittenberg, Elaine/Ferrell Betty/ Goldsmith, Joy/Smith, Thomas/Ragan, Sandra/Glajchen, Myra/Handzo, George F. (eds.), Textbook of Palliative Care Communication. Oxford: Oxford University Press, 44-53.

García-Izquierdo, Isabel/Montalt, Vicent 2013: Equigeneric and intergeneric translation in Patient-Centred care. In Hermes 51, 39-53.

García-Izquierdo, Isabel/Montalt, Vicent 2017: Understanding and enhancing comprehensibility in texts for patients in an institutional health care context in Spain - A mixed methods analysis. In Revista Española de Lingüistica Aplicada 30:2, 592-610. doi: 10.1075/resla.00008.gar.

GarcíaIzquierdo, Isabel/Muñoz-Miquel, Ana 2015: Los folletos de información oncológica en contextos hospitalarios: la perspectiva de pacientes y profesionales sanitarios. In Panace@ 42:16, 225-231.

Grupo Gentt 2016: Entrevista a Anna Lluch. In Panace@ 17:44, 172-174.

Gustin, Jillian/Stowers, Katie H./von Gunten, Charles F. 2015: Communication Education for Physicians In Wittenberg, Elaine/Ferrell Betty/Goldsmith, Joy/Smith, Thomas/Ragan, Sandra/Glajchen, Myra/Handzo, George F. (eds.), Textbook of Palliative Care Communication. Oxford: Oxford University Press, 355-365.

Hacker, Sandra (coord.) 2004: Communicating with Patients - Advice for medical practitioners. Australia: National Health and Medical Research Council. 
Hausberg, Maria C./Hergert, Anika/Kröger, Corinna/Bullinger, Monika/Rose, Matthias/Andreas, Sylke 2012: Enhancing medical students' communication skills: development and evaluation of an undergraduate training program. In BMC Medical Education 12:16. doi: 10.1186/1472-6920-12-16.

Hill-Madsen, Aage 2015: Lexical Strategies in Intralingual Translation between Registers. In Hermes 54, 85-105.

Hojat, Mohammadreza/Mangione, Salvatore/Nasca, Thomas J./Rattner, Susan/Erdmann, James B./Gonnella, Joseph S./Magee, Mike 2004: An empirical study of decline in empathy in medical school. In Medical Education 38:9, 934-941.

Illingworth, Rosie 2015: Patient-Centredness. In Brown, Jo/Kidd, Jane/Noble, Lorraine/Papageorgiou, Alexia (eds.), Clinical Communication in Medicine. New Jersey: John Wiley \& Sons, 40-48.

Hirsh, Di/Clerehan, Rosemary/Staples, Margaret/Osborne Richard H./Buchbinder, Rachelle 2009: Patient assessment of medication information leaflets and validation of the Evaluative Linguistic Framework (ELF). In Patient Education and Counseling 77, 248-254. doi: 10.1016/j.pec.2009.03.011.

Jensen, Matilde N. 2015: Optimising Comprehensibility in Interlingual Translation: The Need for Intralingual Translation. In Maksymski, Karin/ Gutermuth, Silke/Hansen-Schirra, Silvia (eds.), Translation and Comprehensibility. Berlin: Frank \& Timme, 163-194.

Jensen, Matilde N./Zethsen, Karen K. 2012: Translation of patient information leaflets — Trained translators and pharmacists-cum-translators: A comparison. In Linguistica Antverpiensia 11, 31-49.

Kalavana, Theano V. 2015: Responding to Emotions. In Brown, Jo/Kidd, Jane/Noble, Lorraine/Papageorgiou, Alexia (eds.), Clinical Communication in Medicine. New Jersey: John Wiley \& Sons, 91-97.

Kurtz, Suzanne/Silverman, Jonathan/Draper, Juliet 1998: Teaching and Learning Communication Skills in Medicine. Oxford: Radcliffe Medical Press.

Lane, Rob 2015: Breaking Bad News. In Brown, Jo/Kidd, Jane/Noble, Lorraine/Papageorgiou, Alexia (eds.), Clinical Communication in Medicine. New Jersey: John Wiley \& Sons, 98-103.

Lang, Stefan/Esser, Marc 2012: Improving patient communication by writing with empathy. In Medical Writing 21:4, 305-307. doi: 10.1179/2047480612Z.00000000048.

Makoul, Gregory/van Dulmen, Saldra 2015: What Is Effective Doctor-Patient Communication? Review of the Evidence. In Brown, Jo/Kidd, Jane/Noble, Lorraine/Papageorgiou, Alexia (eds.), Clinical Communication in Medicine. New Jersey: John Wiley \& Sons, 30-39.

Martí Ferriol, José Luis 2016: Selection and validation of a measurement instrument for readability calculations in patient information leaflets for oncological patients in Spain. In Journal of Research Design and Statistics 3:1, $110-125$.

Mason, Ian 2000: Audience Design in Translating. In The Translator 6:1, 1-22. doi: 10.1080/13556509.2000.10799053.

Mayer, Richard E./Gallini, Joan K. 1990: When Is an Illustration Worth Ten Thousand Words? In Journal of Educational Psychology 82:4, 715-726.

Montalt, Vicent 2017: Patient-centred translation and emerging trends in medicine and healthcare. In EST NewsletterHot Topics in Translation Studies: Medical Translation and Interpreting, 10-11.

Montalt, Vicent/Ezpeleta-Piorno, Pilar 2018: Roleplay as a research tool used in GENTT's current projects. Paper presented at the IV Gentt International Seminar: Roleplay as an educational and research tool in doctor-patient interaction in multilingual and multicultural settings, 9 November 2018. Castelló de la Plana: Universitat Jaume I.

Montalt, Vicent/García-Izquierdo, Isabel 2016a: Exploring the links between the oral and the written in patient-doctor communication. In Ordóñez-López, Pilar/Edo-Marzá, Nuria (eds.), Medical Discourse in Professional, Academic and Popular Settings. Bristol: Multilingual Matters, 103-124.

Montalt, Vicent/García-Izquierdo, Isabel 2016b: ¿Informar o comunicar? Algunos temas emergentes en comunicación para pacientes. In Panace@ 17:44: 81-84.

Montalt, Vicent/Muñoz-Miquel, Ana/García-Izquierdo, Isabel 2016: Translating genres for patients: challenges for audience design. Paper presented at the $8^{\text {th }}$ EST Congress, 15-17 September 2016. Aarhus: Aarhus University.

Muñoz-Miquel, Ana 2012: From the original article to the summary for patients: Reformulation procedures in intralingual translation. In Linguistica Antverpiensia 11, 187-206.

Muñoz-Miquel, Ana/Ezpeleta-Piorno, Pilar/Saiz-Hontangas, Paula 2018: Intralingual translation in healthcare settings: Strategies and proposals for medical translation training. In MonTI 10, 177-204. doi: 10.6035/MonTI.2018.10.7.

Neubauer, Kathryn/Dixon, William/Corona, Rosalie/Bodurtha, Joann 2015: Cultural Humility. In Wittenberg, Elaine/ Ferrell Betty/Goldsmith, Joy/Smith, Thomas/Ragan, Sandra/Glajchen, Myra/Handzo, George F. (eds.), Textbook of Palliative Care Communication. Oxford: Oxford University Press, 79-89. 
Palos, Guadalupe R. 2015: Cultural Considerations in Palliative Care and Serious Illness. In Wittenberg, Elaine/Ferrell Betty/Goldsmith, Joy/Smith, Thomas/Ragan, Sandra/Glajchen, Myra/Handzo, George F. (eds.), Textbook of Palliative Care Communication. Oxford: Oxford University Press, 153-160.

Petkovic, Jennifer/Epstein Jonathan/Buchbinder, Rachelle/Welch, Vivian/Rader, Tamara/ Lyddiatt, Anne/Clerehan, Rosemary/Christensen, Robin/Boonen, Annelies/Goel, Niti/Maxwell, Lara J./Toupin-April, Karine/De Wit, Maarten/Barton, Jennifer/Flurey, Caroline/Jull, Janet/Barnabe, Cheryl/Sreih, Antoine G./Campbell, Willemina/ Pohl, Christoph/Duruöz, Mehmet Tuncay/Singh, Jasvinder A./Tugwell, Peter S./Guillemin, Francis 2015: Toward Ensuring Health Equity: Readability and Cultural Equivalence of OMERACT Patient-reported Outcome Measures. In The Journal of Reumathology 42 (12), 2448-2459. doi: 10.3899/jrheum.141168.

Prieto-Velasco, Juan Antonio 2017: Recepción y percepción de las imágenes en textos médicos para pacientes: estudio experimental sobre la repulsión. In Panace@18 (45), 50-60.

Quinn Rosenzweig, Margaret 2012: Breaking bad news: A guide for effective and empathetic communication. In The Nurse Practitioner 37:2, 1-4. doi: 10.1097/01.NPR.0000408626.24599.9e.

Ragan, Sandra L. 2015: Overview of Communication. In Wittenberg, Elaine/Ferrell Betty/Goldsmith, Joy/Smith, Thomas/Ragan, Sandra/Glajchen, Myra/Handzo, George F. (eds.), Textbook of Palliative Care Communication. Oxford: Oxford University Press, 1-9.

Ruiz-Moral, Roger/Pérula de Torres, Luis/Monge, Diana/García Leonardo, Cristina/Caballero, Fernando 2017: Teaching medical students to express empathy by exploring patient emotions and experiences in standardized medical encounters. In Patient Education and Counseling 100:9, 1694-1700. doi: 10.1016/j.pec.2017.04.018.

Saiz Hontangas, Paula/Ezpeleta-Piorno, Pilar/Muñoz-Miquel, Ana 2016: El uso de imágenes en guías para pacientes: una primera aproximación desde la perspectiva del nivel de activación del paciente. In Panace@ 44:17, 99-110.

Shaw, Joanne/Dunn, Steward/Heinrich, Paul 2012: Managing the delivery of bad news: An in-depth analysis of doctors' delivery style. In Patient Education and Counseling 87:2, 186-192. doi: 10.1016/j.pec.2011.08.005.

Silverman, Jonathan 2015: Relationship Building. In Brown, Jo/Kidd, Jane/Noble, Lorraine/Papageorgiou, Alexia (eds.), Clinical Communication in Medicine. New Jersey: John Wiley \& Sons, 72-75.

Silverman, Jonathan/Kurtz, Suzanne/Draper, Juliet. 1998: Skills for Communicating with Patients. Oxfod: Radcliffe Medical Press.

Skelton, John 2008: Role Play and Clinical Communication: Learning the Game. Oxford: Radcliffe Publishing.

Sparks, Lisa/Villagran, Melinda M./Parker-Raley, Jessica/Cunningham, Cory B. 2007: Patient-centered approach to breaking bad news: Communication guidelines for health care providers. In Journal of Applied Communication Research 35:2, 177-196. doi: 10.1080/00909880701262997.

Suojanen, Tytti/Koskinen, Kaisa/Tuominen, Tina 2015: User-centered translation. London \& New York: Routledge.

Tate, Peter/Tate, Elizabeth 2014: The Doctor's Communication Handbook. New York: CRC Press (Taylor and Francis Group).

Thompson, Teresa L./Parrott, Roxanne/Nussbaum, John F. 2011: Routledge Handbook of Health Communication. New York: Taylor \& Francis.

Vandekieft, Gregg K. 2001: Breaking Bad News. In American Family Physician 64:12, 1975-1979.

Wittenberg, Elaine/Ferrell Betty/Goldsmith, Joy/Smith, Thomas/Ragan, Sandra/Glajchen, Myra/Handzo, George F. (eds.) 2015: Textbook of Palliative Care Communication. Oxford: Oxford University Press.

Young, Amber/Tordoff, June/Smith, Alesha 2017: 'What do patients want?' Tailoring medicines information to meet patients' needs. In Research in Social and Administrative Pharmacy, 13:6, 1186-1190. doi: 10.1016/j. sapharm.2016.10.006.

Zethsen, Karen K. 2009: Intralingual translation: an attempt at description. In Meta 54:4, 795-812. doi: 10.1556/084.2018.19.1.4.

Zethsen, Karen K. 2018: Access is not the same as understanding. Why intralingual translation is crucial in a world of information overload. In Across Languages and Cultures 19:1, 79-98. doi: 10.7202/038904ar. 


\section{APPENDIX 1}

By way of example, below we include some extracts from the original and improved version of the FSPs. The extracts are in the original language in which they were (re)written, that is, Spanish. The original writing - which includes some spelling and typographical mistakes - has been literally reproduced.

\begin{tabular}{|c|c|}
\hline ORIGINAL VERSION & IMPROVED VERSION \\
\hline $\begin{array}{l}\text { MAREO-SOMNOLENCIA. Puede aparec- } \\
\text { er durante la administración y esta relacionado } \\
\text { con el disolvente que se emplea para diluir el } \\
\text { fármaco, puede mejorar descendiendo el ritmo } \\
\text { de la administración del tratamiento. }\end{array}$ & $\begin{array}{l}\text { Sensación de sueño o mareo. Este efec- } \\
\text { to se produce a causa de las sustancias que se } \\
\text { emplean para diluir el medicamento. Avise al } \\
\text { personal sanitario, que, en caso necesario, re- } \\
\text { ducirá el ritmo de administración del medica- } \\
\text { mento. }\end{array}$ \\
\hline $\begin{array}{l}\text { ALTERACIONES EN EL RITMO CAR- } \\
\text { DIACO, tales como bradicardia, taquicardia } \\
\text { o extrasístoles aunque raramente son causa de } \\
\text { suspender o detener el tratamiento. }\end{array}$ & $\begin{array}{l}\text { Alteraciones en el ritmo cardiaco. El me- } \\
\text { dicamento puede producir que el ritmo al que } \\
\text { late el corazón sea más lento (bradicardia), } \\
\text { más rápido (taquicardia) o irregular (extrasís- } \\
\text { toles). Este tipo de alteraciones raramente ob- } \\
\text { liga a suspender o detener el tratamiento. }\end{array}$ \\
\hline $\begin{array}{l}\text { TOXICIDAD } \\
\text { La medicación intravenosa puede en ca- } \\
\text { sos muy raros invadir los tejidos próximos si } \\
\text { se salen de la luz de la vena. Avise inmediata- } \\
\text { mente si nota en algún momento de la admin- } \\
\text { istración del tratamiento que siente dolor o es- } \\
\text { cozor en la zona de punción. Podría lesionar } \\
\text { el tejido donde se produjera la extravasación. }\end{array}$ & $\begin{array}{l}\text { Salida del líquido fuera de la vena (ex- } \\
\text { travasación). En casos excepcionales (entre el } \\
0,1 \text { y el } 0,9 \% \text { ), el medicamento puede salirse } \\
\text { de la vena y lesionar los tejidos de alrededor. } \\
\text { Avise inmediatamente si en algún momento de } \\
\text { la administración del tratamiento nota dolor o } \\
\text { escozor en la zona de punción. }\end{array}$ \\
\hline $\begin{array}{l}\text { DOLORES MUSCULARES } \\
\text { Se recomienda paracetamol para su control. } \\
\text { No responden a otros analgésicos y suelen de- } \\
\text { saparecer a los } 5 \text { días de manera espontánea. }\end{array}$ & $\begin{array}{l}\text { Dolores musculares } \\
\text { Para aliviarlos, puede tomar paracetamol } \\
\text { (otros analgésicos no son eficaces). Los dolo- } \\
\text { res suelen desaparecer aproximadamente a los } \\
5 \text { días de manera espontánea. }\end{array}$ \\
\hline $\begin{array}{l}\text { REACCIÓN DE HIPERSENSIBILIDAD } \\
\text { O ALERGIA } \\
\text { La primera o la segunda vez que se le ad- } \\
\text { ministra el tratamiento, puede aparecer en los } \\
\text { primeros minutos, dificultad para respirar, pi- } \\
\text { cor generalizado o mareo, avise inmediata- } \\
\text { mente. Se solucionará parando la adminis- } \\
\text { tración de la medicación y/o administrándole } \\
\text { algún fármaco. }\end{array}$ & $\begin{array}{l}\text { Reacción de hipersensibilidad o alergia. } \\
\text { Se puede producir durante los primeros minu- } \\
\text { tos. Avise inmediatamente si tiene dificul- } \\
\text { tad para respirar, picor generalizado o mareo. } \\
\text { Para solucionar estos efectos, el personal san- } \\
\text { itario detendrá la administración intravenosa } \\
\text { o le suministrará otro medicamento. Las re- } \\
\text { acciones alérgicas pueden aparecer la prim- } \\
\text { era o la segunda vez que se le administre Tax- } \\
\text { ol@. No suelen aparecer después de la segunda } \\
\text { administración. }\end{array}$ \\
\hline
\end{tabular}


La principal toxicidad es la neutropenia. [...] Recomendamos que durante los días que tenga la cifra de neutrófilos más baja no se exponga a aglomeraciones y evite el contacto con personas que padezcan algún proceso infeccioso durante todo el tratamiento.

PARESTESIAS son la toxicidad neurológica más común. Se caracteriza por alteraciones en la sensibilidad, sobre todo en pies y manos.
El efecto más frecuente es el descenso de glóbulos blancos (neutropenia), un tipo de células que se encarga de proteger al cuerpo contra las infecciones. [...] Para prevenir infecciones, durante todo el tratamiento y, especialmente, durante los días en que tenga la cifra de glóbulos blancos más baja, debe evitar las aglomeraciones así como el contacto con personas que padezcan algún proceso infeccioso (como resfriado o gripe).

\section{Pinchazos y hormigueos (parestesias). Se} trata de alteraciones de la sensibilidad que se producen con bastante frecuencia. Se manifiestan con sensación de pinchazos, ardor, hormigueos o falta de sensibilidad, sobre todo en los pies y las manos. Puede tener dificultad para abrochar botones, escribir o coger objetos. Tome precauciones cuando maneje objetos afilados, o muy fríos o muy calientes. 